\title{
ÓRIGENOVO POJEDNÁNÍ O SVOBODĚ VŮLE A O SMYSLU MODLITBY K BOHU (DE ORATIONE, 5-7)
}

Spis $O$ modlitbě, který Órigenés sepsal patrně v letech 233-234, zaujímá v souboru jeho díla zvláštní postavení. Převážná část jeho dochovaných textů má totiž povahu komentářu nebo homilií $\mathrm{k}$ jednotlivým biblickým knihám. Vedle nich napsal Órigenés také systematické pojednání $O$ počátcích, věnované základům křest'anské theologie, a poněkud populárnějším zpo̊sobem koncipovanou odpověd’ na útoky, jimiž se proti křest'anům obrátil platónský filosof Kelsos. Na rozdíl od těchto textů je spis $O$ modlitbě věnován rozboru jediného tématu. Zahrnuje však otázky, kterým autor přikládal mimořádnou důležitost a které jeho pojednání udělují obecnější rozměr.

Stejně jako spis Proti Kelsovi sepsal Órigenés text o modlitbě na žádost svého přítele Ambrože hledajícího zřejmě oporu proti některým skeptickým hlasům uvnitř církve, které zpochybňovaly účel modlitby $\mathrm{k}$ Bohu s poukazem na jeho vševědoucnost a neomezenou moc. Jestliže Bůh zná od počátku světa vše, co se stane, neznamená to, že osud každého člověka je již určen dávno před tím, než přijde na svět, a modlitba žádající Boha o pomoc tak ztrácí jakýkoli smysl? Pro Órigenovu reakci na tento postoj je důležité, že Ambrožova žádost se tu setkává s jeho vlastním přáním vyjasnit jeden z klíčových motivů křest'anské theologie, a sice do jaké míry je člověk zodpovědný za vlastní osud. Jak říká Órigenés ve svém výkladu $O$ počátcích křest'anské zbožnosti, jedná se o nanejvýš naléhavou otázku ( $\alpha$ v $\alpha \gamma \kappa \alpha$ ió $\alpha \alpha \tau o v \pi \rho o ́ \beta \lambda \eta \mu \alpha)$, která těsně souvisí s vírou ve spravedlivý Boží soud a jejíž kladné zodpovězení má nezanedbatelný dopad na morálku veřrících. ${ }^{1}$ Neomylnost Boží prozřetelnosti nemůže samozřejmě křest'an, jehož naděje na spásu je cele založena na jeho přesvědčení o pravdivosti Božích proroctví, v žádném případě zpochybňovat. Vedle víry ve všemohoucího Boha, Božího Syna a Svatého Ducha se však úvahy křest'anského theologa musí opřít ještě o jeden

1 Srv. Órigenés, De princ. III,1,1. 
klíčový princip božské ekonomie spásy, a sice o zásadu, že každá duše má ve vztahu k Bohu svobodu volby a Boží odměna či trest, spása či zatracení jsou proto odpovědí na rozhodnutí vycházející z její vlastní vůle. ${ }^{2}$

Úvahy vedené snahou porozumět vztahu těchto dvou klíčových předpokladů křest’anské spásy se opakovaně vynořují v celé řadě Órigenových pojednání, která jsou věnována jiným tematickým okruhům. Způsob, jakým je celý problém nastolen, přitom nedovoluje, aby se Órigenovy argumenty opíraly pouze o biblickou tradici. Ve svém výkladu proto široce využívá diskusí, které se nad otázkou svobodné volby odvíjely v rámci tradičních filosofických škol, aniž by opustil půdu křest'anské víry. Órigenovu analýzu možnosti lidské svobody v rámci světa ovládaného neomylnou Boží prozřetelností tak lze vnímat jako výstižnou zkratku, která do jisté míry shrnuje základní rysy jeho theologie. ${ }^{3}$

V rámci spisu $O$ modlitbě je Órigenův pokus o řešení této ,naléhavé otázky“" soustředěn do tří kapitol, které zde byly předloženy. ${ }^{4} \mathrm{~V}$ následujícím výkladu se pokusím alespoň naznačit, jakým způsobem se proměňuje povaha filosofické argumentace a obsah tradičních filosofických termínů v souvislosti s odlišnou perspektivou Órigenova obrazu křest’anského světa. ${ }^{5}$

\section{Argumenty protivníků modlitby}

$[5,1]^{6} \mathrm{~V}$ první části rozebírá Órigenés námitky těch, kdo pokládají modlitbu za něco zbytečného, co na průběh lidského života nemá žádný vliv.

\footnotetext{
2 Srv. tamt., Praef. $4 \mathrm{n}$.

3 Srv. J. Daniélou, Origène, Paris 1948, str. 204.

4 Viz Órigenés, $O$ modlitbě, 5-7, přel. M. Šedina, str. 101-112 v tomto čísle časopisu.
}

5 Mohu přitom navázat také na poměrně bohatou literaturu z rukou soudobých českých autorů, zejména na knihu M. Navrátila, který přeložil kapitolu věnovanou otázce svobody volby v Órigenově spise $O$ počátcích (De princ. III,1 = Philocal. 21) a opatřil ji poučeným úvodem a důkladnými poznámkami (Órigenés, $O$ svobodě volby, Olomouc 2007), nebo na studie L. Karfíkové v knize Duše, prozřetelnost a svoboda podle Origena (Praha 2018), zvláště na texty Přirozenost a vi̊le podle Origena a Augustina (str. 23-46) a Prožretelnost, osud a svoboda podle Origena a Boethia (str. 109-129). K vyjasnění některých otázek jsem se pokusil přispět také já ve studii Argos logos. Lidská svoboda ve světě Boží vi̊le, in: týž, Sny křest'anských proroků. Svět jako vi̊le a představa v Órigenově polemice s Kelsem, Praha 2018, str. 7-125.

6 Čísla v hranatých závorkách odkazují k př́íslušným oddílům Órigenova spisu. 
Je zřejmé, že tento postoj je vlastní v prvé řadě těm, kdo popírají působení Boží prozřetelnosti nebo v existenci Boha vůbec nevěří, a jejich odmítání modlitby je tedy jen logickým vyústěním jejich atheismu. Snaha vyvrátit jejich stanovisko tedy k vyjasnění sporu o lidskou svobodu v rámci světa vystavěného na bázi Boží prožretelnosti nemůže ničím přispět, a Órigenés proto ponechává stranou také epikúrejskou či peripatetickou obhajobu svobodné vůle.

Skutečnou potíž představují argumenty těch, kdo pochybují o smyslu modlitby přesto, nebo spíše právě proto, že v Boha a jeho prozřetelnost věří. Órigenés je přesvědčen o tom, že tyto postoje vycházejí z chybného výkladu Písma, kterým křest'anští gnostikové zaštit'ují své přesvědčení, že jsou pro svůj výjimečný původ předurčeni ke spáse, a jakékoli další úsilí je tedy v tomto směru zbytečné. Proti nim lze poukázat na „respektované“ zastánce modlitby, mezi které Órigenés bezpochyby zahrnoval především apoštolské a církevní autority. Zmínka o postoji atheistů svědčí však o tom, že měl na mysli také zástupce tradičních filosofických škol, kteří se těmito problémy rovněž zabývali a z jejichž výkladů bude Órigenés v následujícím výkladu čerpat. ${ }^{7}$ Jeho varování, že mezi nimi lze jen těžko najít někoho, kdo by si necenil modlitby, mírí podle všeho proti pokusu křest'anských gnostiků využít zavedených filosofických teorémů $\mathrm{k}$ podpoře vlastních heretických stanovisek. Problém Órigenova postupu spočívá v tom, že křest'anský postoj ke světu stvořenému Bohem biblické tradice je v mnoha ohledech protikladný představám pohanských kosmologů o božské povaze tohoto světa, a tomu odpovídá také rozdíl $\mathrm{v}$ jejich pohledu na povahu a funkci modlitby. Órigenova výtka křest'anským heretikům, že ve skutečnosti ,nehovoří o modlitbě, ale vyučují

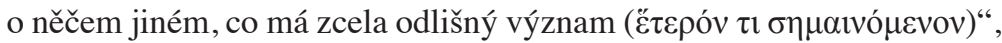
platí tedy do značné míry také pro všechny „respektované“ pohanské filosofy, na jejichž stanovisko se sám odvolává.

$[5,2]$ Tento paradox se ukazuje už v Órigenově expozici ,„p̌resvědčivých důvodů“ ( $\tau$ à $\pi \imath \theta \alpha v \alpha ́$ ), které podle něj uvádějí křest'anští gnostikové pohrdající doslovným (tělesným) významem modlitby, křtu či eucharistie. Jestliže Bůh zná všechny věci dř́ve, než se stanou ( $\pi \rho o ̀ ~ \gamma \varepsilon v \varepsilon ́ \sigma \varepsilon \omega \varsigma$ $\alpha$ $\tau \tilde{\omega} v)$, a jeho prognóza je neomylná, pak je modlitba zbytečná. A protože je Bůh dobrý, „,vede každého ke spáse i bez modlitby“. Třebaže se odpůrci modlitby odvolávají na některá biblická místa, obraz Boha, jak jej zde Órigenés představuje, odráží spíše filosofický fatalismus rodící

7 Srv. B. D. Jackson, Sources of Origen's Doctrine of Freedom, in: Church History, 35, 1966, str. 13-23. 
se v prostředí některých hellénistických škol: „Stoikové tvrdí, že pokud bůh zná všechny věci od počátku, ještě dříve než se stanou (ex initio scit, antequam fiant), " popisuje typický př́klad filosofického determinismu Chalcidius, ,zná od počátku také onu nejistou přirozenost a má v moci i minulé, přítomné a budoucí věci, nebot' bůh se nemůže mýlit." ${ }^{8}$ Tomu pak odpovídá povaha stoické modlitby, která je spíše výrazem smíření filosofa s dobry, jež za něj vybral jeho bůh. ${ }^{9}$ A protože stoický bůh ví předem, co potřebujeme, je zbytečné jej o cokoli prosit.

$[5,3]$ Bůh však budoucí věci nejen zná, ale také je předem uspořádal, seřadil nebo předurčil, argumentují gnostičtí odpůrci tradiční formy modlitby. Také zde se mohli opřít o stoický obraz předem daného osudu. ${ }^{10}$ Pokud jsou tedy i mezi uznávanými stoickými odborníky na otázku božské prozřetelnosti takoví, kteří uznávají význam modlitby, nejde jen o vyjádření poslušnosti vůči bohu, ale o smíření s nevyhnutelným osudem: „Ved’ mne, Die, i ty, všemocný osude, k cíli, kterýs mi kdysi určil, " prosí svého boha Kleanthés. ${ }^{11}$ Osud nelze změnit modlitbou, říká Seneca, a ten, kdo se o to pokouší, neví, co je to bůh (divina non nosti). ${ }^{12}$

Nebezpečí, které se ve stoickém pojetí božské prozřetelnosti skrývá, rozeznali samozřejmě už jeho pohanští kritici. Mají-li stoikové pravdu, že osudu nelze žádným způsobem uniknout, nelze nikoho obviňovat za nespravedlivé nebo zločinné jednání a tresty udělované viníkům jsou nespravedlivé, zní typická výhrada vůči stoickému determinismu. ${ }^{13}$ Tím

8 Chalcidius, In Tim. 160 (= SVF II,943); A. A. Long, Freedom and Determinism in the Stoic Theory of Human Action, in: týž (vyd.), Problems in Stoicism, London 1971, str. 173-199, zde str. 177. K postojům různých stoických škol k tématu svobodné vůle srv. E. Eliasson, The Notion of That Which Depends on Us in Plotinus and Its Background, Leiden - Boston 2008, str. 81-118.

9 Srv. Epiktétos, Diss. IV,7,20; srv. také C. H. Kahn, Discovering the Will. From Aristotle to Augustine, in: J. M. Dillon - A. A. Long (vyd.), The Question of „Ecclecticism“, Berkeley 1988, str. 234-259, zde str. 254: „Epiktétos v mnoha ohledech anticipuje duchovní postoj křest'anských autorů, jako byl Augustin.“

10 Srv. Chalcidius, In Tim. 160 (= SVF II,943): „Vše je uspořádáno a ustanoveno, jak věci, které jsou prý v naší moci, tak i náhodné události. A protože bylo o všech věcech rozhodnuto předem, stává se podle stoiků vše podle osudu (ex fato).“

11 Epiktétos, Ench. 53 (= SVF I,527); Diss. IV,1,131.

12 Srv. Seneca, Natur. quaest. II,35 nn.; Ep. 95,47-49; Marcus Aurelius, Ad se ipsum, IX,40; G. Dorival, Modes of Prayer in the Hellenic Tradition, in: J. Dillon A. Timotin (vyd.), Platonic Theories of Prayer, Leiden - Boston 2016, str. 37 n.

13 Srv. Aulus Gellius, Noctes Att. VII,2 (= SVF II,1000). K dalším dokladům srv. C. Stough, Stoic Determinism and Moral Responsibility, in: J. M. Rist (vyd.), The Stoics, Berkeley 1978, str. 203-231. 
spíše se této představě vzpírají obránci křest'anské víry. Justin Mučedník důrazně varuje před tím, abychom pravdivost předpovědí o tom, co se odehrálo kolem Ježíšova př́íchodu, obhajovali odkazem na jeho osudové předurčení. Kdyby tomu tak bylo a vše se dělo nutností osudu ( $\alpha \alpha \theta^{\prime}$

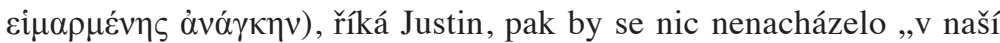

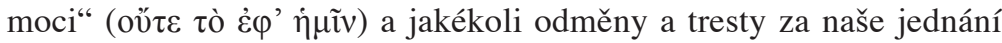
by ztratily smysl. Bůh však na počátku stvořil člověka jako svobodnou bytost ( $\alpha$ $\tau \varepsilon \xi o v ́ \sigma ı v)$, a dobré či špatné skutky činí tedy každý podle

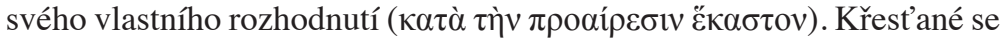
proto ve své naději na spásu nesmějí spoléhat na předurčení, jako to činí stoikové, podle kterých se vše odehrává nutností osudu. ${ }^{14}$

$[5,4]$ Podle gnostických odpůrců modlitby lze nicméně podobné argumenty odkrýt v samotné apoštolské tradici. Pavlův výklad v Listu Římanům zdůrazňuje například váhu Božího vyvolení, které určuje postavení Jákoba či Ezaua dávno před tím, než se narodili, a může tak vyvolávat pochybnosti o Boží spravedlnosti. Ve svém pojednání $O$ počátcích uvádí Órigenés v oddílu věnovaném svobodě lidské vůle, že právě o tyto Pavlovy výroky opírají heretičtí gnostikové své přesvědčení, že naše spása či zatracení jsou určeny předem, nebot' Bůh má vše ve své moci a jako hrnčír ,udělal z téže hroudy jednu nádobu ke vznešeným účelům a druhou ke všedním“. ${ }^{15}$ Pavel podle nich dodává legitimitu jejich spekulacím o rozdělení Adamova pokolení do tří základních typů ( $\varphi v ́ \sigma \varepsilon 1 \varsigma)$, které předurčují lidský osud. Následovníci Valentina, Basileida či Prodika nepochybují o tom, že oproti předem zatraceným hylikuim

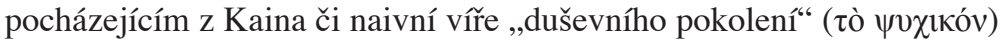
Ábelových potomků, kteří doufají, že si svou spásu dokážou vymodlit, byli právě oni předem „odděleni již v těle své matky“ jako duchovní pokolení ( $\tau$ ò $\pi v \varepsilon v \mu \alpha \tau$ เóv ), a proto jim „,i bez modlitby připadne to nejkrásnější “. ${ }^{16}$

14 Srv. Justin, Apol. I,43,1 nn.; II,7,4 n. Podobně Tatian, Or. 7,3.

15 Órigenés, De princ. III,1,21, k $\check{R}$ 9,21; tamt., III,1,8; III,4,5: „Někteří heretici tvrdí, že jsou stvořeny různé přirozenosti duše (diversas naturas animarum), které jsou od přirozenosti určeny k záchraně nebo k záhubě“.

16 Srv. Irenaeus, Adv. haer. I,6,1-4; Klement Alexandrijský, Strom. II,10 n.; Exc. Theod. 56,3: „Duchovní pokolení je spaseno od přirozenosti ( $\tau$ ò $\pi v \varepsilon v \mu \alpha \tau$ เ⿵òv $\varphi v ́ \sigma \varepsilon 1$

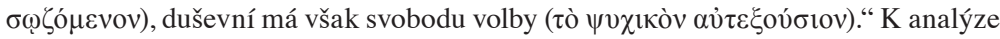
tohoto motivu na základě textu Adamovy apokalypsy $(75,1-8)$ srv. L. Schottroff, Animae naturaliter salvandae, in: W. Eltester (vyd.), Christentum und Gnosis, in: Beihefte zur Zeitschrift für die neutestamentliche Wissenschaft, 37, 1969, str. 65-97. $\mathrm{K}$ vazbám těchto gnostických představ na novozákonní a židovskou tradici srv. G. E. 
[5,5] Zdá se, že tento gnostický model předurčené spásy či zatracení tak docela neodmítá ani Órigenés, když vinu za vlastní osud přičítá „starším příčinám“ ( $\tau \alpha \grave{\alpha} \pi \rho \varepsilon \sigma \beta v ́ \tau \varepsilon \rho \alpha) .{ }^{17} \mathrm{Na}$ rozdíl od heretiků, kteří formování vlastního osudu kladou do rukou Boha, však vidí Órigenés příčinu ve svobodné volbě rozumných bytostí, které Bůh na počátku stvořil naprosto stejné, jejich vlastní vůle je však nakonec dovedla k různým formám života. ${ }^{18}$ Přesto se Órigenův výklad dostává velice blízko k filosofickým východiskům, která inspirovala také jeho heretické protivníky. Jejich přesvědčení, že osud člověka je určen předem, se zřejmě v řadě případů opíralo spíše o platónskou filosofickou tradici, v tomto př́ípadě o Platónův obraz podsvětní distribuce životů, během níž si každá duše volí svou životní roli už před svým zrozením. ${ }^{19}$

Také Platónova obhajoba lidské zodpovědnosti za vlastní osud však v sobě skrývá omezení, které je z křest'anského pohledu jen těžko přijatelné. Platón sice zdůrazňuje, že se jedná o svobodnou volbu, a bůh je tedy „bez viny“, duše si však vybírají z omezeného počtu možností daných potřebami božského kosmu. Výstižnou ilustrací způsobu, jakým jednotlivé duše uplatňují svou „vůli“, je koneckonců skutečnost, že některé si „volí“ život nerozumných zviřat. ${ }^{20} \mathrm{Z}$ životního tvaru, který si jednou zvolily, se navíc již nemohou žádným způsobem vymanit a ti, kdo změnili názor, se „modlí marně“ - „nebudou vyslyšeni, i kdyby se pomodlili tisíckrát“. ${ }^{21}$ Vždyt' co by to bylo za bohy, kdyby se nechali uprosit, ř́íká Platón v Zákonech, a jak by se to vůbec srovnávalo s ne-

Sterling, Wisdom Among the Perfect. Creation Traditions in Alexandrian Judaism and Corinthian Christianity, in: Novum Testamentum, 37, 1995, str. 355-384.

17 Srv. Órigenés, De princ. III,1,21; M. Šedina, Argos logos, str. 87 n.

18 Srv. Órigenés, De princ. II,9,6.

19 Srv. Platón, Resp. 617d nn.; Leg. 903d-904e. Sám Órigenés se na tento Platónův mýtus odvolává v Contra Cels. II,16. Podle H. Kocha, Pronoia und Paideusis. Studien über Origenes und sein Verhältnis zum Platonism, Berlin - Leipzig 1932, str. 201, pozn. 2, můžeme právě zde hledat jedno z východisek Órigenových úvah o svobodě volby. Srv. také B. D. Jackson, Sources of Origen's Doctrine of Freedom, str. $16 \mathrm{n}$.

20 Právě tato etická dvojznačnost platónského konceptu byla zřejmě důvodem nejistoty, s jakou důvod sestupu duše k tělu glosuje středoplatónský autor spisu $D i$ -

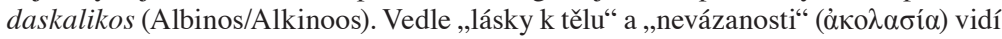
příčinu ve „vůli bohů“ a v ,číselném rozvrhu“, který patrně odkazuje k Platónově zmínce o roli „nutnosti“ (srv. Albinos/Alkinoos, Didasc. 25,6; Platón, Tim. 42a).

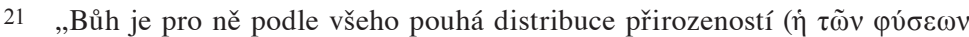
$\delta 1 \alpha v o \mu \eta ́)$, která nepřipouští základ spásy, to jest dobrovolnou víru “" shrnuje tuto platónskou inspiraci valentinovské gnóze Klement Alexandrijský (Strom. II,11,2). 
úhybnou logikou kosmické prožretelnosti? ${ }^{22}$ Órigenova obhajoba smyslu modlitby $\mathrm{k}$ Bohu zahrnuje naopak předpoklad, že rozumná duše disponuje svobodou volby za každých okolností, jak před svým sestupem do těla, tak po něm. ${ }^{23}$

Způsob, jakým je tato otázka vyostřena v prostředí křest’anské theologie, dokládá podle Órigenova mínění př́íklad Jidáše, jehož modlitba je nejen naprosto neúčinná, ale je mu dokonce „počítána za hřích“, přestože o jeho zradě bylo rozhodnuto dávno před jeho zrozením, jak o tom svědčí dochovaná proroctví z Davidových časů. Jako by tedy byla Jidášovi předem určena role zrádce, které se pak nutně přizpůsobuje také jeho povaha a jeho nejvnitřnější záměry a touhy. Takový člověk se pak nemůže se svými prosbami k bohům vůbec obracet, ř́ká už Platón, nebot' to, co je dobrému člověku prospěšné, se u zlého obrací v pravý opak. ${ }^{24}$ Díky Órigenovi se nám ovšem dochovala autentická reakce platónského filosofa na podobný druh biblických proroctví. Ve spisu Proti Kelsovi cituje Órigenés Kelsův názor, že předpovědí Jidášovy zrady Ježíš sám přivedl tohoto svého učedníka na scestí. ${ }^{25}$

Charakteristické je, že ve spisu Proti Kelsovi hájí Órigenés Jidášovu svobodu volby poukazem ke způsobu, jakým se stoikové ohrazovali

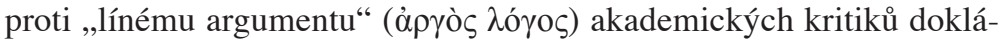
dajících fatální důsledky jejich koncepce neúhybného osudu na každodenní lidský život. ${ }^{26} \mathrm{~V}$ pojednání $O$ modlitbě není tento motiv výslovně vztažen k línému argumentu, jeho logika se nicméně odráží v obraze biblického krále Jóšijáše, který žádá Boha o věci, jež mu byly přisou-

22 Srv. Platón, Leg. 905d-e.

23 Srv. Órigenés, De princ. I,6,3; B. D. Jackson, Sources of Origen's Doctrine of Freedom, str. 14 n. Křest'anská duše nepřichází do smrtelného těla ,podle Platónovy nauky o převtělování duší, ale ve shodě s jiným učením, které směřuje mnohem výše“, zdůrazňuje opakovaně Órigenés (srv. Contra Cels. IV,17; M. J. Edwards, Origen against Plato, Aldershot 2002, str. 105 n.).

24 Srv. Platón, Leg. 717a: „Marná je tedy lidem bezbožným velká námaha vztahující se k bohům, avšak všem zbožným je nejprospěšnějšíi“" Svou povahu dostává totiž duše podle toho, jaký život si před svým vtělením zvolí, vysvětluje Platón v Resp. 618b. Srv. Órigenovu ironickou poznámku na toto téma in: Philocal. 23,9: Je to stejné, jako kdyby Bůh předpověděl, že Jidáš nebude nikdy létat.

25 Srv. Órigenés, Contra Cels. II,20.

26 Srv. tamt. (= SVF II,957); srv. Cicero, De fato, 12,28 nn.; SVF II,956; 957. Órigenův výklad rozebírá např. S. Bobzien, Determinism and Freedom in Stoic Philosophy, Oxford 2004, str. 180 nn. Srv. také M. Šedina, Argos logos, str. 11 nn. 
zeny už za jeho předchůdců. Proč by se měl tedy „pracně namáhat“

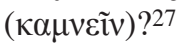

$[5,6]$ Navzdory řadě biblických citací se tedy oba hlavní argumenty křest'anských kritiků modlitby - neomylná božská znalost budoucích věcí, stejně jako neměnnost Boží vůle ( $\alpha \rho \alpha \rho o ́ \tau \alpha \beta o v \lambda \varepsilon v ́ \mu \alpha \tau \alpha)$ - nakonec opírají především o filosofický koncept božské prozřetelnosti, který vyrostl na půdě pohanské kosmologie..$^{28}$ „Každému, kdo si je vědom rozsahu moci Božího rozumu, je i bez Písma ze samotného pojmu Boha zřejmé, že Bůh ví o jakékoli budoucí události dlouho před tím, že se stane, “ ř́ká Órigenés v Komentáři ke Genesi. ${ }^{29}$ Jeho obraně modlitby se tak nabízí podobný postup jako ve sporu s Kelsem o svobodnou vůli Jidáše, kdy proti názorům platónského filosofa postavil námitky, které uplatňovali stoikové proti akademické kritice jejich konceptu neúhybného osudu. ${ }^{30}$

\section{Předběžné poznámky: filosofická východiska Órigenovy obrany svobodné vůle}

$[6,1]$ V pozadí Órigenova pokusu o filosofické vyvrácení závěrů, které podněcují netečnost vůči modlitbě, stojí tentokrát stoická představa souvislého božského pneumatu, které proniká všemi věcmi tohoto světa a jehož napětí ( đóvos) určuje povahu jednotlivých okruhů bytí. Stoikové rozlišovali na této škále čtyři základní stupně: soudržnost (๕̌ $\left.\xi_{1 \zeta}\right)$, utvářená pohybem pneumatu vracejícího se k sobě samému, působí v kamenech, růst ( $\varphi v ́ \sigma ı \varsigma)$ charakterizuje bytí rostlin, duše ( $\psi v \chi \eta ́)$ zajišt'uje instinktivní

27 Takový postoj lze přirovnat k poblouznění melancholika, který se domnívá,

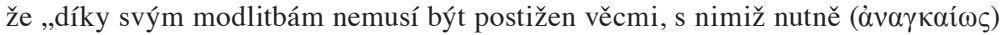
zápasí celý lidský rod“" (srv. výše, Or. 5,3).

28 Srv. Osbornovo shrnutí těchto námitek kritiků modlitby v kapitole příznačně nazvané „Svět prozřetelnosti“ (E. Osborn, The Intermediate World in Origen's „On Prayer“, in: H. Crouzel - A. Quacquarelli (vyd.), Origeniana secunda, Roma 1980, str. 98 n.).

29 Órigenés, Philocal. 23,4.

30 Věštba o Jidášově zradě je podle Órigena př́íkladem složeného výroku, jaký například varoval krále Laia před zplozením syna (srv. týž, Contra Cels. II,20). Tento oidipovský motiv přejímá Órigenés rovněž ze stoických diskusí o relevanci „líného argumentu“" (srv. Cicero, De fato, 13,30; Lúkianos, Jup. conf. 13; S. Bobzien, Determinism and Freedom in Stoic Philosophy, str. 199 nn.; 208). 
pohyb živočichů, rozum ( $\lambda$ ó ${ }$ ) $)$ umožňuje člověku posuzovat představy vlastní všem živým bytostem a rozhodovat se, jakým způsobem na ně bude reagovat. Také tato scala naturae představovala zřejmě stoický pokus o harmonizaci vztahu mezi jednotným božským principem, který přirozeně ovládá osud všech věcí tohoto světa, a výlučností lidského bytí. ${ }^{31}$

Órigenés se ve svém výkladu soustřed’uje především na rozdílné př́činy pohybu, který tyto jednotlivé stupně bytí charakterizuje. Oproti stoikům vidí kupodivu hlavní dělítko nikoli mezi pohybem rozumných bytostí a pohybem ostatních článků této škály, ale mezi pohybem, který k jednotlivým věcem přistupuje ,zvnějšku“ ("̌ $\xi \omega \theta \varepsilon v)$, a pohybem, kterým se věci a bytosti pohybují ,ze sebe“ ( $\dot{\varepsilon} \xi \alpha$ $\alpha \tilde{\tau} \tilde{\omega} v)$, tedy pohybem rostlin a živočichů. Že sem patř́i také rozumné bytosti, dokládá Órigenův výklad o svobodě volby z třetí knihy jeho spisu $O$ počátcích, který se rovněž opírá o stoickou charakteristiku jednotlivých okruhů bytí. Proti věcem, jako je mrtvé dřevo nebo kámen, které jsou „spojeny toliko svou soudržností", staví vše, co má prríčinu svého pohybu „v sobě“, co je tedy soudržné „díky přirozenosti a duši“. Třebaže pak poukazuje na výlučnost lidského rozumu, který nám na rozdíl od zviriat dává možnost posuzovat, přijímat nebo odmítat představy, které $\mathrm{k}$ nám přicházejí zvnějšku, dodává $\mathrm{k}$ tomu, že podobný druh chování můžeme zaznamenat také u některých nerozumných živočichů, vycvičených k určité specifické činnosti. Nebot' „přirozenost“" ( $\varphi v ́ \sigma ı \varsigma)$ vedoucí k nějaké činnosti je ve větší či menší mîre vlastní všem živočichům, vysvětluje Órigenés. ${ }^{32}$ „Pokud tedy věci probíhají popsaným způsobem, není oprávněné ani rozumné dávat naše jednání na vinu vnějším podnětům, a stavět nás tak vlastně na stejnou úroveň se dřevem a kamením, které se pohybují výhradně silou působící zvnějšku. “33

31 Srv. F. Karfík, TO EF' HMIN mezi Aristotelem a stoiky, in: týž, Duše a svět, str. 129-149, zde str. 143.

32 Órigenés, De princ. III,1,3: „Počínání honicích psů či válečných koní je díky

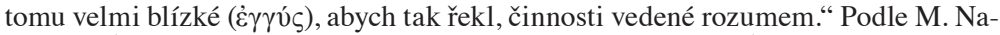
vrátila, Órigenés, $O$ svobodě volby, str. 261, pozn. 14, zde Órigenés ,chce ostře vyznačit rozdíl mezi původem jednání živočichů bez rozumu a u bytostí obdařených rozumem“. Tímto směrem ukazuje také Rufinův „překlad“ tohoto místa. S tím nemohu souhlasit, zvláště když se v případě těchto zvířat jedná o projev „výcviku“, a nikoli pouhých instinktů. Srv. Órigenés, De princ. III,1,4, ke způsobu, jakým si „,vede člověk více vzdělaný a vycvičený v naukách“.

33 Tamt. III,1,5 (= SVF II,990). 
[6,2] Právě v tomto základním rozlišení mezi věcmi, které jsou po-

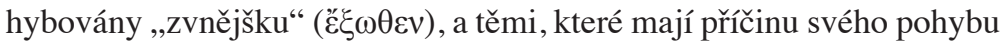
„V sobě“ (

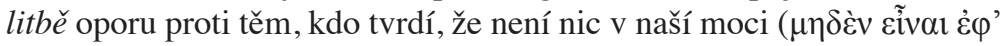

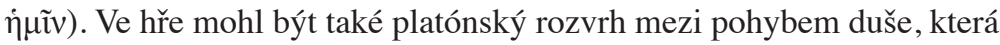
je v dialogu Faidros definována jako „to, co se pohybuje samo od sebe“

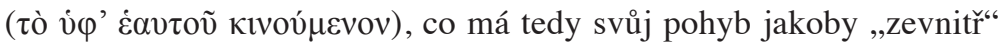
(๕̌v $\delta \circ \theta \varepsilon v)$, a pohybem těla bez duše, které je pohybováno ,zvnějšku“ $(\check{\varepsilon} \xi \omega \theta \varepsilon v) .{ }^{34}$ Stejně jako v prrípadě podsvětní volby životů bylo ovšem Platónovo rozlišení těchto pohybů těsně spjato s naukou o převtělování duše, která vstupuje také do těl nerozumných zvîrat. Bez nebezpečí není však ani Órigenova snaha využít stoické analýzy racionálního pohybu.

Výstižným příkladem je jeho pokus o aplikaci stoického pojmu „sou-

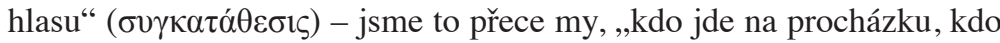
s něčím souhlasí, kdo přijímá nějaké nauky a jiné odmítá jako falešné“. 35 Toto spojení je patrně ohlasem na stoické úvahy, jakou roli vlastně hraje souhlas v našem uvedení do pohybu: „Je vhodné, abych se procházel. Jdu se procházet, pokud si to řeknu a tomuto úmyslu přitakám," vysvětluje Seneca, „,co je to souhlas“ (quid sit adsensio). ${ }^{36}$ Obecně vzato je tento souhlas vyhrazen pouze pro rozumné bytosti. Zatímco nerozumní živočichové se nevědomky nechávají vést představami, které přicházejí zvnějšku, člověk si tyto představy uvědomuje a dokáže je posuzovat co do jejich pravdivosti a užitečnosti pro jeho vlastní život: „Bohové vložili v naši moc jen to, co je nejlepší ze všeho, tj. schopnost správného užívání představ.“37 Jak to sám Órigenés vyjadřuje ve svém rozvinutí stoické škály v třetí knize spisu $O$ počátcích: „Rozumný živočich má vedle představivosti rozum, který posuzuje představy, přičemž jedny od-

34 Srv. Platón, Phaedr. 245e. B. D. Jackson, Sources of Origen's Doctrine of Freedom, str. 17, upozorňuje také na analogická místa v Platónových Zákonech (893b nn.). Srv. také E. Osborn, The Intermediate World in Origen's „On Prayer“, str. 99.

35 Srv. SVF I,61, z Cicerona: „K představám, které jsme získali díky svým smyslům, připojuje Zénón souhlas duše (assensio animorum), který je prý svobodný a je v naší moci.“ K dalším dokladům srv. C. H. Kahn, Discovering the Will, str. 246-248; V. Mikeš, Stoická teorie jednání. Pojem přitakání, in: Reflexe, 34, 2008, str. 3-28.

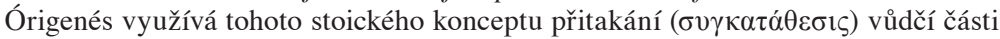
našim představám také v De princ. III,1,4 n.

36 Seneca, Ep. 113,18 (= SVF II,169).

37 Epiktétos, Diss. I,1,7; srv. tamt., I,6,13-22. Podobnou formulaci tohoto rozdílu známe také z Platóna, který v etymologiích dialogu Kratylos odvozuje jméno člověka od jeho schopnosti ,zkoumat to, co uviděl“, nebot' ostatní živočichové žádnou z věcí, které vidí, neprohlížejí, neuvažují o ní ani ji nezkoumají (Platón, Crat. 399c). 
mítá a jiné přijímá.“38 Toto využití motivu svobodného souhlasu je pro alexandrijskou školu typické. Stejným způsobem jako Órigenés navazoval na stoickou škálu bytí Klement Alexandrijský, který zdůrazňoval, že schopnost rozvažování, jež je vlastní lidské duši, není spoutána pudy

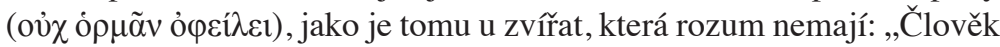
může rozlišovat své představy a není jim vydán napospas.“39 Pokud se tedy nechá svést nepřátelskými mocnostmi, které před jeho tělesný či duševní zrak kladou klamné obrazy dobra, mohou za to nejen tyto vnější

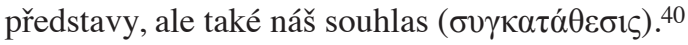

Stoický pojem rozumu ( $\lambda$ ó $\varsigma_{\text {o }}$ ) je ovšem natolik spojen s přirozeným pudem (ópuí), který každého živočicha žene za tím, co je mu vlastní, že se samotný motiv souhlasu může jen těžko stát skutečným garantem svobody a zodpovědnosti: „Všechny popudy jsou přitakání.“41 Když tedy Órigenés prohlašuje, že k tomu, abychom se odhodlali (óp $\mu \tilde{\alpha} v)$ jít třeba na procházku, ale také abychom ,chválili nebo kárali v přesvědčení, že naše svobodná vůle je zajištěna a že chvála nebo hana vychází od nás samých“, nás „nutí“ evidentní pravdivost našeho přesvědčení, že jsme to my, kdo jde na procházku nebo kdo s něčím souhlasí, dostává se velice blízko k pojmu stoické racionality, která se podobně jako rozumnost ve službě platónského kosmu dokáže uplatnit právě tak dobře v mysli filosofa jako v těle „,nerozumného“ živočicha. ${ }^{42}$ Nemluvě o kamenech,

38 Órigenés, De princ. III,1,3.

39 Srv. Klement Alexandrijský, Strom. II,111,2. Srv. také Filónovy formulace v Quod Deus sit immut. 45-48, a R. Radice, Philo and Stoic Ethics. Reflections on the Idea of Freedom, in F. Alesse (vyd.), Philo of Alexandria and Post-Aristotelian Philosophy, Leiden - Boston 2008, str. 163.

40 Pro naše téma je důležité, že v diskusi s heretickými gnostiky, pro které je víra ,vyšší kvalitou přirozenosti“, definuje Klement křest’anskou víru jako „svobodně přijatou anticipující představu“ či ,zbožné přitakání“, o němž „,platónští filosofové i stoikové říkají, že je v naší moci“ (srv. Klement Alexandrijský, Strom. II,8,4; 11,1 n.; 54,5).

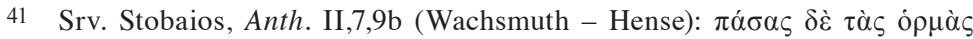

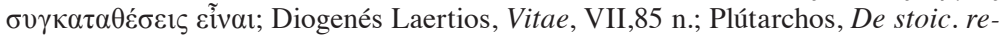
pugn. 1037 n. (= SVF III,175): „Pud je podle Chrysippa rozum člověka, který mu nařizuje něco učinit.“

42 Srv. Rufinův překlad Órigenova popisu živočišného instinktu v De princ. III,1,2: „Je to jakási vůle či popud, který vyvolává podráždění a tíhnutí k něčemu“ (id est voluntas quaedam vel incitamentum, adfuerit, quae ea moveri ad aliquid vel incitari provocaverit). Podle C. Stough, Stoic Determinism, str. 206, Órigenovy poznámky výstižně ilustrují ,způsob, jakým osud a nutnost podle názoru stoiků působí např́čc celou přírodou“. 
které jsou součástí pohybu „rudných žil““: „Pohyby v naší mysli nejsou totiž nic než nástroje k uskutečnění toho, co bylo rozhodnuto osudem. “43

[6,3] Jako definitivní stvrzení Órigenovy závislosti na těchto starých kosmologických představách se pak může jevit jeho argument, že v důsledku Boží předpovědi „přijímá svobodná vůle každého člověka ve správě veškerenstva takovou roli, která je potřebná pro udržení kosmického řádu“. Jeho formulace připomíná Platónovu výzvu k modlitbě za „spásu“ veškerenstva, na níž se z logiky věci musí podílet všechny jeho části, resp. všechny živé bytosti, které zajišt'ují jeho pravidelný chod: „Všechno dění má ten účel, aby bylo životu veškerenstva uskutečňováno št'astné bytí, takže se neděje kvůli tobě, nýbrž ty jsi pro ono veškero,“ upozorňuje Platón své čtenáře v Zákonech. ${ }^{44}$ Je zjevné, že filosofičtí prosebníci, kteří se obracejí k tomuto „viditelnému bohu“, od něj ve skutečnosti nečekají žádnou odezvu. Jejich modlitba má spíše kontemplativní charakter oslavující netečnou atraktivitu božských obrazů kosmu a jejím cílem je zajistit náležité soustředění duše, aby se mohla bezbolestně zapojit do dokonalého, a právě proto také „,neúprosného“ mechanismu pečujícího o pravidelný chod tohoto světa. ${ }^{45}$

Órigenův důraz na potřebu ,zajistit“ v prvé řadě svobodu lidského jednání svědčí nicméně o úplně jiném pojetí racionality, než jaké nabízela platónská či stoická představa kosmu uspořádaného božskou prozřetelností. Svět pro něj není vzorem dokonalosti, jemuž se každá jednotlivá bytost snaží instinktivně připodobnit, ale životním prostorem, který Bůh stvořil pro všechny rozumné bytosti jako místo jejich spásy. ${ }^{46}$

43 Chalcidius, In Tim. 161 (= SVF II,943); Alexandros z Afrodisiady, De fato, 13 (= SVF II,979); k dalším dokladům srv. A. A. Long, Freedom and Determinism, str. 177 n., který ovšem upozorňuje, že většina podobných výroků pochází od „nepřátelských svědků“ (hostile sources). K Órigenově pozici v rámci této tradice srv. C. Stough, Stoic Determinism, str. 220 n.

44 Srv. Platón, Leg. 903c-d. Jak podotýká B. D. Jackson, Sources of Origen's Doctrine of Freedom, str. 17, Platónův výklad by klidně mohl pocházet z Órigenova pera.

45 Srv. Platón, Tim. 27c-d; Criti. 106b; Leg. 893b. H. S. Benjamins, Eingeordnete Freiheit, str. 110, upozorn̆uje v této souvislosti také na způsob, jakým Platónův démiúrgos „uvedl v řád“ vše, co bylo dosud neuspořádané (Platón, Tim. 30a).

46 Srv. Órigenés, Contra Cels. VI,44; H. Koch, Pronoia und Paideusis, str. $41 \mathrm{n}$. Pouze za těchto okolností platí, že ,také naše modlitby jsou včleněny do toho řádu, a proto si podržují svůj smysl“, jak Órigenův výrok o „udržení kosmického řádu“ interpretuje L. Karfíková, Preexistence duše podle Origena a Augustina ve světle biblického verše Ef 1,4, in: táž, Duše, prožretelnost a svoboda podle Origena, str. 47-87, zde str. 56. 
To a nikoli sama rozumnost je odlišuje od nerozumných zviŕrat, která nedokážou rozlišovat mezi tím, co je v tomto spásném pohybu dobré, a co zlé. Pokud má svět tuto funkci skutečně naplnit, nemůže být svoboda lidské volby jen nějakým doplňkovým aspektem kosmické prožretelnosti, ale musí stát v samotných základech jeho konstrukce. Jestliže tedy

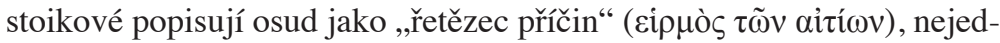
ná se z pohledu křest’anského theologa o nějaký předem daný, „věčný a nezměnitelný sled věcí“ (sempiterna quaedam et indeclinabilis series rerum et catena), z něhož se nelze vymanit, jak si to představovali stoikové. ${ }^{47}$ Boží prozřetelnost spravující tyto věci sice projevy lidské vůle časově předchází, logicky je však následuje, a stoické argumenty jsou tak paradoxně použity proti představám založeným právě na stoickém obrazu světa. ${ }^{48}$ Podoba světa je výsledkem toho, co Bůh předem zahlédl „,v každém činu svobodné vůle“, z níž vychází „,sled budoucích událos-

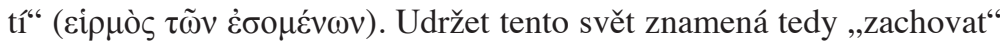

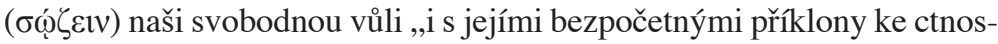
ti nebo ke špatnosti““. ${ }^{9}$

\section{Modlitba ve světě křest’anské spásy}

$[6,4]$ Bůh tedy ví, co se stane a oč budeme prosit, nikoli proto, že nás takové stvořil, ale právě proto, že ,zná předem věci, které jsou v moci

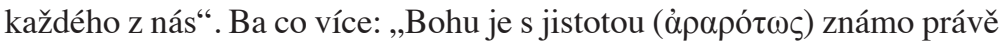

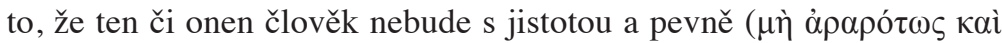
$\beta \varepsilon \beta \alpha i \omega \varsigma)$ chtít to lepšíi“ Jak říká Órigenés v Komentáři ke Genesi: „Je to stejné, jako když vidíme člověka, který se z nevědomosti ukvapuje a navzdory rozumu unáhleně vstupuje na kluzkou dráhu. Třebaže jsme si vědomi, že dotyčný uklouzne a upadne, neznamená to, že jsme příčinou toho, že na tuto klouzačku vstoupil." 50

47 Srv. Seneca, Natur. quaest. II,35; SVF II,917; 920; 1000, z Aula Gellia. Srv. také Plútarchovu definici v De fato, 570d-e: „To, co je osudové a co se děje podle

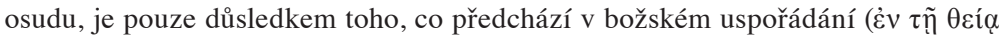
$\delta 1 \alpha \tau \alpha \dot{\xi} \varepsilon 1) . “$

48 Srv. P. J. van der Eijk, Origenes' Verteidigung des freien Willens, str. 339 a 343.

49 Podobnou argumentaci uplatňuje Órigenés v Komentáři k Listu Římanůn v reakci na gnostický projekt předem spasených ,přirozeností“ (srv. řecký text in: Órigenés, Philocal. 25,2; L. Karfíková, Prozrretelnost, osud a svoboda podle Origena a Boethia, str. 113 n.; srv. níže, str. 129, k ospravedlnění Pavla).

50 Srv. Órigenés, Philocal. 23,10. 
V takovém prostoru je pak základním konstrukčním prvkem lidského osudu právě modlitba, na kterou Bůh odpovídá podle míry její spásné

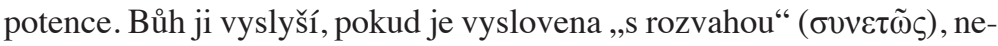
vyslyší naopak požadavky, které jsou v rozporu s jeho spásnými záměry nebo jsou předneseny „,nedbale“ ( $\alpha \mu \varepsilon \lambda \tilde{\omega} \varsigma)$. Stejné varování směřuje Platón $\mathrm{k}$ těm, kdo nedokážou rozeznat skutečné dobro a často nevědomky žádají boha ve svých modlitbách o pravý opak. Takový člověk se ve skutečnosti nemodlí, ale spíše sám sebe proklíná. ${ }^{51}$ Jak jsme ovšem viděli, o svém údělu na tomto světě rozhoduje platónský člověk definitivně ještě před svým narozením, kdy si jeho duše vybírá v podsvětí svůj budoucí osud a pro svou nedostatečnou dialektickou akribii si ukvapeně volí život, jehož výhody zakrývají zla, která jsou s ním spojena..$^{52} \mathrm{O}$ životě, do něhož vstupuje křest'anská duše, lze naopak s jistou nadsázkou říci, že jej Bůh udělil duši právě kvůli modlitbě, která má odčinit její prvotní nedbalost vedoucí k odpadnutí od Boha, nikoli přispět ke „št’astnému bytí" veškerenstva.

To je také důvod, proč Bůh ve své odpovědi na modlitbu odmítá poskytnout věci, které by prosebníkovi nebyly ku prospěchu, a proč mu na druhé straně poskytuje neskonale více, než oč je schopen požádat. Zatímco platónské duše si volí své budoucí osudy z určitého počtu životních tvarů, které božský démiúrgos vytvořil podle ideálního vzoru dobře uspořádaného kosmického celku, křest'an, který již není zodpovědný za svět, ale za svůj vlastní osud, podobné „klasické“ měřítko spásy postrádá. $V$ důsledku toho vzrůstají jeho možnosti změnit svůj přirozený úděl, a tedy i míra zodpovědnosti za vlastní budoucnost. Bůh, který zná předem lidská rozhodnutí, tak sice neurčuje naše budoucí skutky, napomáhá nám ale tam, kde naše vủle $\mathrm{k}$ dobru naráží na hranice naší omezené lidské perspektivy.

O tom, do jaké míry se váha a účinek modlitby přsesouvá do rukou samotného prosebníka, svědčí také status andělských služebníků, kteří tomuto spásnému pohybu napomáhají a kteří představují Órigenovu odpověd na slabost lidského poznání, na niž upozorňují odpůrci modlitby (srv. Or. 5,2). Bůh nám nemůže dát něco, co nechceme, dokud jsme však nedokonalí, potřebujeme $\mathrm{k}$ tomu, abychom se vymanili z obtíží, pomocníka, kterého už Jákob nazýval ,andělem, jenž mne chránil před vším

51 Srv. Platón, Alc. II, 138b; 143b; 148b nn. Stejným směrem mírí Sókratova modlitba v závěru dialogu Faidros (Phaedr. 279b-c).

52 Srv. týž, Resp. 617d-619e. 
zlým“. 53 Také tito strážní andělé mohou připomínat platónské daimony, které bohyně osudu přiděluje každé duši jako „strážce života“ dohlížející na důsledné naplnění jejího životního údělu. Modlitby vznášené k těmto „bohům“ pak pouze sledují průběh podsvětního obřadu, jímž duše utvrdila nezměnitelnost své životní volby, když se spolu se svým daimonem rituálně dotkla vřetene Nutnosti. ${ }^{54} \mathrm{Z}$ pohledu křest'anského theologa stvrzuje ovšem tento vázací akt spíše podřízení lidské duše bytostem, které kvůli své nedbalosti či lenosti odpadly od Boha ještě hlouběji než ona, a nelze tedy od nich očekávat, že by nás ,pozdvihly od země ke svému příbuzenstvu na nebi““.55 Jinak je tomu v případě andělů, kteří se naopak rozhodli zůstat v blízkosti Boha a jejichž sestup k člověku protiřečí logice „líného argumentu“ ve stejné mîre jako křest'anská modlitba. Namísto toho, aby zůstali v nečinnosti, se při pohledu na příklad Krista ujímají po vzoru „dobrých lékařư“ vedení těch, kteří se obracejí zpět k Bohu. 56

To je ovšem možné pouze tehdy, pokud se člověk vymaní z moci sil, které se naopak pokoušejí udržet lidské duše v rámci náboženských a kosmologických konstrukcí ovládajících svět pohanů. Lidská duše, která se pohybuje v tomto prostředí, není předem zatracena jako hylikové křest’anských gnostiků, ale podobně jako Ezau, který i ve svém pozemském životě pokračuje ve svém pádu od Boha, „ochabne vůči vyšším

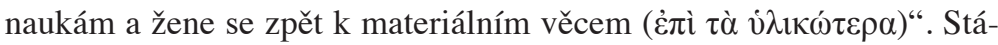
vá se tak „ochotným“ zajatcem démonických bytostí, které padly ještě níže než člověk. Takoví jsou například „bohové pohanů“, kteří si mezi sebou rozdělili jednotlivé okrsky tohoto světa a v očích řeckých filosofü

53 Srv. Órigenés, Comm. Math. XII,26, ke Gn 48,16.

54 Srv. Platón, Resp. 620d nn. Př́́kladem může být Sókratova modlitba k Erótovi uzavírající jeho palinodii v dialogu Faidros (Phaedr. 244a-257b), ale také jeho modlitba k Panovi v závěru téhož dialogu s příznačnou prosbou o soulad toho, co je vně, s tím, co vládne jeho nitru (srv. tamt., 279b-c; K. Gaiser, Das Gold der Weisheit, in: Rheinisches Museum, 132, 1989, str. 105-140).

55 Platón, Tim. 90a; srv. Órigenés, De princ. III,2,4, s odkazem na Barn. 18 a Hermova pastýře, Mand. 6,2, jehož popis anděla spravedlnosti a anděla špatnosti připomíná Platónovu metaforu dvou koní vynášejících duši k nebesům (srv. Phaedr. $253 \mathrm{c}$ nn.).

56 Srv. Órigenés, Hom. Ez. I,7: Quid nos quiescimus? quid parcimus nobis? Podobně v Órigenově Contra Cels. VIII,34: „Těmto lidem se zjevují a soudí, že jejich úkolem je vyslechnout je a přijít k nim jakoby na základě společné smlouvy, aby prokázaly dobrodiní a přinesly spásu těm, kdo se obrací s prosbami k Bohu, k němuž se modlí i ony samy.“ 
představují jakési „dohlížitele“ nad dodržováním jeho tradičního řádu. Protože však Bůh stvořil tento svět kvůli záchraně člověka, přispívají nakonec také tyto padlé mocnosti svým pohybem k naplnění božské ekonomie spásy. ${ }^{57}$

[6,5] V závěru šesté kapitoly pak Órigenés uvádí některé konkrétní př́klady, jak Bůh ,přredem pořádá“ prostor lidské spásy. Bůh si byl vědom toho, že Jóšijáš se vzepře démonickým tradicím střežícím obraz pohanského kosmu, a připravil mu proto na pomoc anděla s odpovídajícími „ctnostmi““.

Úplně jiný případ představuje Jidáš, o němž Bůh předem věděl, že „bude nejprve ušlechtilým a dobrým člověkem, později se však změní a upadne do lidských hř́íchů“. Órigenův důraz na lidskou svobodu volby jej vede k tomu, že na rozdíl od jiných křest’anských autorů své doby hodnotí Jidáše mnohem subtilnějším způsobem a vidí v něm spíše typický př́íklad selhání lidské duše, která ,ppo tom všem, co jí bylo dáno“, ochabla vůči vyšším naukám ( $\lambda$ ó $\mathrm{k}$ materiálním věcem. ${ }^{58}$ Právě na něm lze pak také demonstrovat sílu

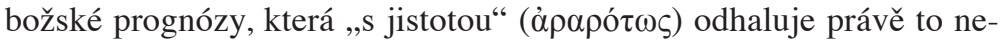
jisté, co se v člověku skrývá: „Ve svém postoji k učiteli upadl Jidáš do rozporuplného a vzájemně si protiřečícího úsudku,“vysvětluje Órigenés v odpovědi na Kelsovu kritiku Ježíšova „pokryteckého“ vztahu k jeho žákům. ${ }^{59}$ Podobné rozpaky provázejí ostatně chování apoštola Petra, který stál Ježíšovi mnohem blíže než Jidáš, do poslední chvíle jej ujištoval o své věrnosti, a přece jej zapřel, jak mu to Ježíš předpověděl.$^{60}$ Právě z jeho selhání je zřejmé, jak pošetilé jsou představy heretických gnostiků, podle kterých je lidský osud předem dán, a naše spása tedy nezávisí na svobodě volby, ale „,na našem uzpůsobení, přijatém od toho, kdo nás právě takto uzpůsobil““. Petrova slabost a váhavost nám ukazuje, že ani on, který by mohl být pokládán za reprezentanta „duchovního pokolení“ par excellence, není nějakou ,předem spasenou přirozeností““ 61

57 Srv. týž, Contra Cels. VI,44: „Protože Bůh ví, jak využít potřebným zpo̊sobem také následky zla, musel takové zlé bytosti včlenit do universa a vytvořil školu ctnosti pro ty, kdo se rozhodli zápasit o ni podle pravidel.“

58 Srv. týž, De orat. 6,4.

59 Týž, Contra Cels. II,11; srv. týž, Philocal. 23,9.

60 Srv. týž, Contra Cels. II,15; Mt 26,35.

61 Srv. týž, De princ. I,8,2; III,1,18. Gnostikové se přitom odvolávali na varování před „špatnými stromy“, které přece nemohou nést dobré ovoce, v Matoušově evangeliu (srv. Mt 7,15-20; M. Šedina, Argos logos, str. 77 n.). 
Tím spíše to platí o Pavlovi, který byl podle svých vlastních slov Bohem „vyvolen“ ke zvěstování evangelia „už v těle své matky“, z čehož někteří vyvozují, že nebyl vyvolen a ospravedlněn kvůli svému vlastnímu svobodnému rozhodnutí, ale na základě své ,přirozenosti“. ${ }^{62}$ V Komentáři k Listu Římanům nicméně Órigenés upozorňuje na přesný význam Pavlových formulací, z nichž jednoznačně vyplývá, že Bůh předem určil, povolal a ospravedlnil ty, ,které si předem vyhlédl“ 63 To znamená, že svůj pohled upřel na sled událostí, které povedou k rozhodnutí Pavlovy svobodné vůle (

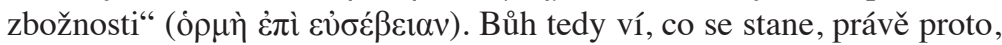
že se to stane „,Z vlastního podnětu jednajícího člověka“, a předem tak pořádá vše ,podle toho, co zahlédl v každém činu svobodné vůle“ (Or. $6,3){ }^{64}$

O tom, že Bůh si nevyvolil Pavla kvůli jeho ,přirozenosti“, svědčí také sled událostí, které nakonec vedou k jeho ospravedlnění. Je všeobecně známo, že během pronásledování církve spáchal Pavel mnoho bezbožných skutků. Bůh však díky své znalosti budoucích věcí ( $\tau$ à

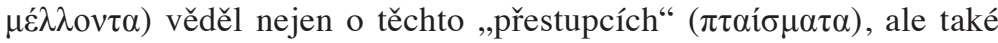
o tom, s jakým úsilím se nakonec Pavel rozhodne pro cestu spásy. Právě na základě těchto budoucích rozhodnutí si jej Bůh vyvolil dříve, než přistoupil ke stvoření světa, a „,v okamžiku jeho zrození“ jej svěřil „silám, které spolupracují na lidské spáse“. A proto na rozdíl od pneumatických gnostiků, kteří „,vědí“ o tom, že jsou předem spaseni, si Pavel plně uvědomuje míru vlastní zodpovědnosti za svůj osud a nepolevuje v modlitbách apelujících na Boží milost. ${ }^{65}$

62 Srv. $\check{R} 1,1 ; 8,30 ;$ Ga 1,15 n. K předem ospravedlněné „přirozenosti“ viz také Órigenés, De princ. III,1,8; výše, str. 117 v tomto čísle časopisu.

63 Srv. $\check{R} 8,29$.

64 Srv. Órigenés, Philocal. 25,2; H. S. Benjamins, Eingeordnete Freiheit, str. 107-109; L. Karfíková, Prožretelnost, osud a svoboda podle Origena a Boethia, str. 113 n.; výše, str. 107-108 v tomto čísle časopisu.

65 Srv. Órigenés, De princ. I,8,2, k 1 K 15,9; týž, Philocal. 23,10, ke slabosti těch, kdo jsou si na základě Božího př́slibu jisti svou spásou: „Pokud se nám ale předem dostane poznání, že se v každém případě staneme krásnými a dobrými, oslabuje to

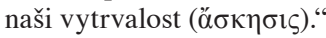




\section{Modlitba k „nebeskému zástupu“}

[7] Sedmá kapitola spisu $O$ modlitbě pak podtrhuje charakter světa stvořeného Bohem kvůli lidské spáse. Stejným způsobem, jakým „využil svobodné vůle všech pozemských bytostí $\mathrm{k}$ tomu, aby je $\mathrm{k}$ jejich prospěchu náležitě uspořádal“", využívá Bůh svobodné vůle nebes-

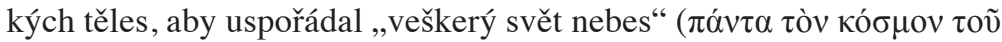
ov̉pavoṽ).

Za živé bytosti obdařené duší pokládal hvězdy už Platón, který ovšem nehovořil o jejich svobodné vůli, ale o jejich racionalitě, díky níž jejich pohyb bezchybně odráží dokonalost nehybného ideálního vzoru, podle něhož byl uspořádán tento svět. ${ }^{66}$ Autor platónského dialogu Epinomis vidí jádro této racionality právě v tom, že nebeská tělesa „dělají stále totéž, protože dělají, co je dávno rozhodnuto, již podivuhodně dlouhý čas“. Na rozdíl od lidí tak „nemění svá rozhodnutí““ a nečiní „brzy to, brzy něco jiného“, nebot' jejich pohyb je ovládán nutností náležející duši, která vlastní nejvyšší formu rozumu, a která proto volí vždy to, co je nejlepší ${ }^{67}$ To jsou vlastnosti, které z jejich uspořádání činí obraz nejvyššího boha, idol, k němuž se se svými obět'mi a modlitbami obrací ti, kdo jsou schopni těmto neměnným požadavkům božského rozumu přizpůsobit dráhy vlastní duše a po smrti následovat dráhy jejich dobře vyvážených kolesek až na samotný vrchol nebes. ${ }^{68}$

Podobnou výzvu můžeme zaznamenat také u Órigena, který ve spisu Proti Kelsovi zdůrazňuje, že naše úcta ke hvězdám se nemá týkat jejich „viditelného světla“, ale „rozumného a pravdivého světla“, které v sobě tyto rozumné a ctnostmi obdařené živé bytosti nesou díky poznání pocházejícímu od Moudrosti, která je „odleskem věčného světla“. Podotýká nicméně, že zatímco jejich viditelné světlo je dílem tvůrce universa, „rozumné světlo je patrně jejich vlastní a vychází z jejich svobodné vůle“.69 Právě proto, že se jedná o „rozumné bytosti“ (rationabiles ani-

66 Srv. Platón, Tim. 37d nn.; 40a-b. S obrazem hvězd jako živých bytostí se Platón obrací proti řeckým prŕírodovědcům, kteří slunce, měsíc a hvězdy nepokládali za bohy, ale za pouhé neživé kameny (Leg. 886d-e). O hvězdách jako o bytostech,

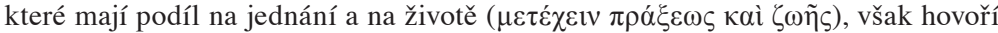
také Aristotelés v De Caelo, II,12,292a19-21 a za božské bytosti, které „cítí a myslí“ (sentire atque intellegere), pokládali hvězdy rovněž stoikové (srv. Cicero, De nat. deor. II,15,39).

67 Srv. Platón, Epin. 982b-d.

68 Srv. týž, Tim. 47b-c; Phaedr. 246d nn.; Epin.988a.

69 Srv. Órigenés, Contra Cels. V,10; Mdr 7,26. 
mantes), mohou hvězdy také hřešit, upozorňuje Órigenés v první knize svého spisu $O$ počátcích.$^{70}$ Přestože tedy Órigenés zdůrazňuje roli hvězd pro stabilitu kosmu, jsou podle něj i ony součástí stejné spásné ekonomie jako lidské duše sestupující k pozemskému životu. ${ }^{71}$

Miroslav Šedina

70 Srv. Órigenés, De princ. I,7,2 n.; Comm. Ioann. I,35,257. Jako „hříšníci“ jsou hvězdy popisovány např. v knize Henoch, kde jsou trestány za to, že opustily své předepsané dráhy (srv. 1Hen 18,13-16; 80,6; Iz 24,21; A. Scott, Origen and the Life of the Stars, str. 92). Srv. proti tomu Aristotelovu úvahu o „rozumné“ svobodě hvězd, jimž je podobně jako svobodným členům řecké domácnosti na rozdíl od otroků a domácích zvířat „nejméně dovoleno jednat podle libosti“ (Aristotelés, Met. 1075a19-22).

71 Srv. Órigenés, Contra Cels. V,11: „Také slunce, měsíc a hvězdy se modlí prostřednictvím jednorozeného Syna k Bohu veškerenstva.“ Kdyby nemuselo zůstat trvale ve svém nebeském těle, i slunce by raději zemřelo, aby se mohlo vydat na cestu k Bohu, ř́ká s jistou nadsázkou Órigenés (De princ. I,7,5). 